\title{
IMPLEMENTASI DEMOKRASI PANCASILA DALAM SISTEM PEMILIHAN KEPALA DESA
}

\author{
Hasyim Adnan \\ Fakultas Hukum Universitas Islam Bandung \\ hasyim_adnan17@yahoo.com \\ DOI : https://doi.org/10.29313/sh.v17i1.5363
}

\begin{abstract}
ABSTRAK
Demokrasi merupakan sebuah kumpulan ide dan prinsip tentang kebebasan, bahkan juga mengandung sejumlah praktik dan prosedur untuk mencapai kebebasan yang terbentuk melalui perjalanan yang panjang dan berliku. Pancasila sebagai dasar Negara Kesatuan Republik Indonesia terdiri dari nilai-nilai agama, adat istiadat dan kebudayaan. Eksistensi daerah atau wilayah tertentu yang relatif independen dan mempunyai sistem pemerintahan lokal yang khas dan diteruskan secara berkesinambungan yang sampai sekarang masih dapat ditelusuri, seperti halnya, Desa di Jawa, Marga, Kuria, Huta, Nagari, Gampong (semuanya di Sumatera) dan nama lain bagi beberapa kelompok tertentu yang tersebar di nusantara pada waktu dulu. Demokrasi Pancasila seharusnya berpengaruh sekali terhadap sistem pemerintahan desa di Indonesia, hal itu dapat terlihat diantaranya dari pemilihan kepala desa yang diselenggarakan secara langsung.
\end{abstract}

\section{Kata kunci: Demokrasi, Pancasila, Pemilihan Kepala Desa}

\section{ABSTRACT}

Democracy is a set of ideas and principles of freedom, even also contains a number of practices and procedures to achieve the freedom that is formed through a long and winding journey. Pancasila as the basis of a unitary State of the Republic of Indonesia consists of religious values, customs and culture. The existence of a particular region or regions that are relatively independent and has the typical local government system and forwarded on an ongoing basis which until now can still be traced, as is the case, a village in Java, clan, Kuria, Huta, Nagari, Gampong (in Sumatra) and other names for some specific groups scattered across the archipelago at the time first. Pancasila democracy was supposed to take effect once the system of Government of a village in Indonesia, it can be seen from the village chief elections which were held directly.

Keywords: Democracy, Pancasila, the election of the head of the village 


\section{PENDAHULUAN}

\section{A. Latar Belakang Masalah}

Secara etimologis kata demokrasi dalam bahasa Yunani adalah bentukan dari dua kata, demos (rakyat) dan cratein atau cratos (kekuasaan dan kedaulatan). Perpaduan kata demos dan cratein atau cratos tersebut membentuk kata demokrasi yang memilki pengertian umum sebagai sebuah bentuk pemerintahan rakyat (government of the people), kekuasaan tertinggi berada di tangan rakyat dan dilakukan secara langsung oleh rakyat atau melalui para wakil mereka melalui mekanisme pemilihan yang berlangsung secara bebas. ${ }^{1}$

Berdasarkan sejarahnya, demokrasi sering bersanding dengan kebebasan (freedom). Tetapi, demokrasi dan kebebasan tidaklah identik, demokrasi merupakan sebuah kumpulan ide dan prinsip tentang kebebasan, bahkan juga mengandung sejumlah praktik dan prosedur untuk mencapai kebebasan yang terbentuk melalui perjalanan sejarah yang panjang dan berliku. Secara singkat, demokrasi merupakan bentuk institusionalisasi dari kebebasan (institusionalization of freedom). Jadi, apakah suatu pemerintahan dapat dikatakan demokratis atau tidak, terletak pada sejauh mana pemerintahan tersebut berjalan pada prinsip konstitusi, hak asasi manusia, dan persamaan warga negara di hadapan hukum. ${ }^{2}$ Pancasila sebagai dasar negara Republik Indonesia sebelum disahkan pada tanggal 18 Agustus 1945 oleh Panitia Persiapan Kemerdekaan Indonesia, tetapi nilai-nilainya telah ada pada bangsa Indonesia sejak zaman dahulu kala sebelum bangsa Indonesia mendirikan negara, yang berupa nilai-nilai adat istiadat, kebudayaan serta nilai-nilai religius. ${ }^{3}$

Isi arti sila-sila Pancasila pada hakikatnya dapat dibedakan atas hakikat Pancasila yang umum universal dan merupakan substansi sila-sila Pancasila,

${ }^{1}$ Ubaedillah \& Abdul Rozak, Pendidikan Kewarga(Negara)an Civic Education, Kencana Prenada Media Group, Jakarta, 2012, hlm. 66.

${ }^{2}$ Ibid., 66-67.

${ }^{3}$ Kaelan, Pendidikan Pancasila, PARADIGMA, Yogyakarta, 2010, hlm. 28. 
sebagai pedoman pelaksanaan dan penyelenggaraan negara yaitu bersifat umum kolektif serta realisasi pengamalan Pancasila yang bersifat khusus dan konkrit. Hakikat Pancasila merupakan nilai, sedangkan norma merupakan pedoman negara, dan aktualisasi atau pengamalannya merupakan realisasi konkrit Pancasila. Substansi Pancasila dengan kelima silanya yang terdapat pada Ketuhanan, Kemanusiaan, Persatuan, Kerakyatan dan Keadilan merupakan suatu sistem nilai. ${ }^{4}$

Pancasila sebagai suatu dasar filsafat negara, maka sila-sila Pancasila merupakan suatu sistem nilai. Oleh karena itu, sila-sila Pancasila itu pada hakikatnya merupakan suatu kesatuan. Meskipun dalam setiap sila terkandung nilai-nilai yang memiliki perbedaan antara satu dengan lainnya, tetapi semuanya itu merupakan suatu kesatuan yang sistematis. ${ }^{5}$ Sejarah eksistensi Pancasila sebagai dasar filsafat negara Republik Indonesia mengalami berbagai macam interpretasi dan manipulasi politik sesuai dengan kepentingan penguasa demi kokoh dan tegaknya kekuasaan yang berlindung di balik legitimasi ideologi negara Pancasila. Berdasarkan kenyataan tersebut, gerakan reformasi berupaya untuk mengembalikan kedudukan dan fungsi Pancasila sebagai dasar negara Republik Indonesia.

Otonomi daerah sebagai aplikasi dari konsep desentralisasi seperti dikenal sekarang ini, sangat sulit mencarinya dalam praktek kerajaan-kerajaan atau kesultanan yang ada di nusantara sebelum kedatangan penjajah di abad XVI. Pola hubungan antara kerajaan atau kesultanan dengan daerah taklukannya atau yang mengakuinya sebagai raja atau sultan lebih bercorak hubungan atasan dan bawahan atau pengakuan formal lewat pembayaran pajak, atau upeti secara regular. Artinya, daerah taklukan membayar upeti atau

${ }^{4}$ Ibid., hlm. 72.

${ }^{5}$ Ibid., hlm. 79. 
persembahan setiap tahun dan kewajiban-kewajiban lainnya kepada raja atau sultan yang menjadi penguasa tertinggi di daerah tersebut. ${ }^{6}$

Sejarah nusantara mencatat bahwa pusat-pusat kekuasaan yang berupa kerajaan atau kesultanan tersebar mulai dari Aceh sampai ke bagian timur nusantara. Seperti diketahui ada Sriwijaya yang berpusat di Palembang, Majapahit yang berpusat di Jawa, Mataram yang berpusat di Jawa. Berikut beberapa kesultanan yang terkenal seperti kesultanan Aceh, kesultanan Deli, kesultanan Siak, kesultanan Banten, kesultanan Gowa, kesultanan Kutai, kesultanan Tidore, dan lain-lain. ${ }^{7}$

Eksistensi daerah atau wilayah tertentu yang relatif independen dan mempunyai sistem pemerintahan lokal yang khas dan diteruskan secara berkesinambungan yang sampai sekarang masih dapat ditelusuri seperti halnya, Desa di Jawa, Marga, Kuria, Huta, Nagari, Gampong (semuanya di Sumatera) dan nama lain bagi beberapa kelompok tertentu yang tersebar di nusantara pada waktu dulu. ${ }^{8}$ Demokrasi Pancasila seharusnya berpengaruh sekali terhadap Sistem Pemerintahan Desa di Indonesia, hal itu dapat terlihat diantaranya dari Pemilihan Kepala Desa (Pilkades) yang diselenggarakan secara langsung. Pemerintahan Desa sekarang ini menjadi sorotan publik, hal itu dikarenakan diundangkannya Undang-undang Nomor 6 Tahun 2014 tentang Desa, diantaranya Pemilihan Kepala Desa (Pilkades) secara langsung, dan masa jabatan Kepala Desa dibatasi hanya tiga periode saja, serta masa jabatan Kepala Desa dibatasi juga setiap periodenya hanya enam tahun saja. Maka dalam hal ini peranan implementasi demokrasi Pancasila sangat diperlukan dalam sistem Pemilihan Kepala Desa. Berdasarkan sejarahnya dalam peraturan perundangundangan di Indonesia, Pemerintahan Desa dimasukkan sebagai satu kesatuan dalam Undang-Undang Nomor 22 Tahun 1999 tentang Pemerintahan Daerah.

${ }^{6}$ B.N. Marbun, Otonomi Daerah 1945-2010 Proses \& Realita, Sinar Harapan, Jakarta, 2010, hlm. 27.

${ }^{7}$ Ibid., hlm. 28

${ }^{8}$ Ibid. 
Hal itu berbeda dengan pengaturan Pemerintahan Desa pada masa Orde Baru (ORBA), Desa diatur secara khusus dalam Undang-Undang Nomor 5 Tahun 1979 tentang Pemerintahan Desa, yang terpisah dengan Undang-Undang Nomor 5 Tahun 1974 tentang Pokok-Pokok Pemerintahan Daerah.

Secara substansial, Undang-Undang Nomor 5 Tahun 1979 sepenuhnya mencerminkan stelsel dan pendekatan yang memisahkan Pemerintahan Desa dari Pemerintahan Daerah. Pemisahan tersebut dipengaruhi oleh pikiran terhadap makna mempertahankan keaslian desa sebagaimana dijumpai dalam Penjelasan UUD 1945 (sebelum diubah). ${ }^{9}$ Kemudian terjadi perubahan peraturan perundang-undangan yang mengatur tentang Desa, yaitu dengan disahkannya Undang-Undang Nomor 6 Tahun 2014 tentang Desa. Desa diberikan keleluasaan untuk mengurus rumah tangganya sendiri dengan keaslian desa. Berdasarkan Undang-Undang Nomor 6 Tahun 2014 tentang Desa, perubahan terhadap Pemerintah Desa seharusnya meliputi aspek penyelenggaraan Pemerintahan Desa dan pelaksanaan pembangunan Desa. ${ }^{10}$ Perubahan terhadap partisipasi dan kesejahteraan masyarakat desa seharusnya berasal dari pembinaan kemasyarakatan desa dan pemberdayaan masyarakat desa. ${ }^{11}$ Sehingga supaya semuanya itu dapat tercapai, maka implementasi Demokrasi Pancasila dalam Sistem Pemilihan Kepala Desa itu harus dapat terealisasisikan.

Penelitian ini hendak mengungkap implementasi Demokrasi Pancasila dalam Sistem Pemilihan Kepala Desa. Penelitian ini dilakukan untuk meneliti implementasi Demokrasi Pancasila dalam Sistem Pemilihan Kepala Desa, yang dihubungkan dengan Undang-undang Nomor 6 Tahun 2014 tentang Desa. Studi

${ }^{9}$ I Gde Pantja Astawa, Problematika Hukum Otonomi Daerah di Indonesia, Alumni, Bandung, 2009, hlm. 329.

${ }^{10}$ Pasal 2 Undang-undang Nomor 6 Tahun 2014 tentang Desa.

${ }^{11}$ Nata Irawan, Tata Kelola Pemerintahan Desa Era UU Desa, Yayasan Pustaka Obor Indonesia, Jakarta, 2017, hlm. 3 . 
kasusnya pelaksanaan pemilihan kepala desa secara serentak di Kabupaten Banyumas yang diikuti oleh 785 orang calon kepala desa (kades) di 257 desa, yang tersebar di beberapa kecamatan diantaranya Kecamatan Tambak, Kecamatan Sumpiuh, Kecamatan Kemranjen, Kecamatan Kebasen, Kecamatan Banyumas, Kecamatan Kalibagor, Kecamatan Wangon, Kecamatan Sumbang, Kecamatan Cilongok, Kecamatan Kedung, dan Kecamatan Ajibarang.

\section{B. Perumusan Permasalahan}

Mengacu kepada latar belakang permasalahan yang sudah diuraikan, dapat diidentifikasikan permasalahan utama yang akan dikaji yaitu bagaimana implementasi Demokrasi Pancasila dalam Sistem Pemilihan Kepala Desa (studi kasus pemilihan kepala desa secara serentak di Kabupaten Banyumas)?

\section{Metode Penelitian}

Metode penelitian dalam penulisan ini bersifat deskriptif analitis yaitu menggambarkan dan menganalisis data yang diperoleh berdasarkan data sekunder. Metode pendekatan yang digunakan adalah yuridis normatif, yang lebih menitikberatkan pada studi kepustakaan, yang selanjutnya dianalisis secara yuridis kualitatif.

\section{PEMBAHASAN}

\section{A. Demokrasi Pancasila di Indonesia}

Prinsip kedaulatan rakyat diatur dalam Pasal 1 ayat (2) UUD 1945 yang menyebutkan, bahwa: "Kedaulatan berada di tangan rakyat dan dilaksanakan menurut undang-undang dasar". Rakyat yang menentukan corak dan cara pemerintahan diselenggarakan. Rakyat yang menentukan tujuan yang hendak dicapai oleh negara dan pemerintahannya itu. ${ }^{12}$ Prinsip ini sangat perlu dibudayakan mulai dari kultur berorganisasi dalam Pemilihan Umum (Pemilu), Pemilihan Kepala Daerah (Pilkada) dan Pemilihan Kepala Desa (Pilkades). Demokrasi telah menjadi istilah yang sangat diagungkan dalam sejarah

12 Jimly Asshiddiqie, Pengantar Ilmu Hukum Tata Negara, RajaGrafindo Persada, Jakarta, 2009, hlm.414. 
pemikiran manusia tentang tatanan sosio-politik yang ideal. Bahkan, untuk pertama kali dalam sejarah, demokrasi dinyatakan sebagai nama yang paling baik dan wajar untuk semua sistem organisasi politik dan sosial yang diperjuangkan oleh pendukung-pendukung yang berpengaruh. ${ }^{13}$ Kedudukan yang sentral dari demokrasi ini telah mengenyampingkan teori-teori lainnya mengenai tatanan kekuasaan yang baik, yang pernah ditawarkan oleh kalangan filsuf, ahli hukum, dan pakar ilmu politik hingga awal ketiga millenium ini. ${ }^{14}$ Kepercayaan yang kuat atas sempurnanya teori politik demokratis belum dapat tergeserkan secara filosofis, sosiologis, maupun dalam format yuridis ketatanegaraan. Kedudukan sentral ini bahkan semakin menguat diiringi dengan konsep-konsep lain, seperti human rights, civil society, maupun konsep good governance, yang pada akhirnya menegaskan posisi teori demokrasi sebagai konsep terbaik yang pernah dicapai oleh pemikiran manusia. ${ }^{15}$

Demokrasi dipercayai sebagai gagasan universal yang dapat diterima dalam ragam perspektif. Demokrasi telah menjadi obsesi sejumlah masyarakat non-Barat semenjak awal abad ke-20. Banyak wilayah jajahan Barat di Asia dan Afrika mulai bergerak untuk mewujudkan nilai-nilai demokrasi di dalam masyarakat. Kemudian melalui demokrasi yang diperoleh dengan pendidikan

\footnotetext{
${ }^{13}$ Penrnyataan ini merupakan hasil penelitian yang diselenggarakan oleh UNESCO pada tahun 1949, yang dimuat oleh Miriam Budiardjo dalam bukunya Dasar-dasar Ilmu Politik yang diterbitkan Gramedia pada tahun 1996 (Cetakan ke-10). Bunyi lengkapnya adalah "probably for the first time in history, democracy is claimed as the proper ideal description of all systems of political and social organizations advocated by influential proponents". Dinyatakan pula bahwa sesudah Perang Dunia II, bahwa secara formil demokrasi merupakan dasar dari kebanyakan negara di dunia. Hendra Nurtjahjo, Filsafat Demokrasi, Bumi Aksara, Jakarta, 2008, hlm. 1

${ }^{14}$ Ibid.,

${ }^{15}$ Ibid, hlm. 1-2.
} 
Barat, para pemuka masyarakat wilayah jajahan ingin mengembangkan nilainilai demokrasi yang akan digunakan untuk membebaskan diri dari belenggu penjajahan. Pada zaman Hindia Belanda, gejala seperti ini dinamakan sebagai Kebangkitan Nasional. ${ }^{16}$ Gambaran ini tidak hanya terjadi dalam sejarah kebangkitan nasional Indonesia saja, tetapi hampir di seluruh belahan dunia, gerakan demokratisasi kehidupan politik telah menjadi fenomena yang tak terelakkan dalam mengubah persepsi sejarah tentang bagaimana menyelenggarakan kekuasaan secara etis, rasional, dan bertanggungjawab. Demokrasi mempunyai potensi untuk memberikan yang terbaik bagi manusia, terutama dalam melindungi hak-hak individu dalam menghadapi kekuasaan negara dan kekuasaan pemerintah. Proses transformasi sejarah yang terjadi pada era modern ini merupakan proses yang menghapuskan segala bentuk pemerintahan yang tidak demokratis ataupun antidemokratik, dan yang kemudian menegakkan bentuk pemerintahan serta sistem politik yang demokratis. $^{17}$

Demokrasi terus berkembang, dan menurut Bagir Manan bahwa demokrasi merupakan suatu fenomena yang tumbuh, bukan suatu penciptaan. Oleh karena itu, praktik di setiap negara tidak selalu sama. Walaupun demikian, sebuah negara dapat dikatakan demokarsi paling tidak memenuhi unsur-unsur yaitu: (1) ada kebebasan untuk membentuk dan menjadi anggota perkumpulan; (2) ada kebebasan menyatakan pendapat; (3) ada hak untuk memberikan suara dalam pemungutan suara; (4) ada kesempatan untuk dipilih atau menduduki berbagai jabatan pemerintah atau negara; (5) ada hak bagi para aktivis politik

16 Maswadi Rauf, Demokrasi dan Demokratisasi: Penjajakan Teoretis untuk Indonesia, Pidato Pengukuhan sebagai Guru Besar Madya dalam Ilmu Politik FISIP UI, 1 November 1997. Dikutip oleh Hendra Nutjahjo, ibid., hlm. 2.

${ }^{17}$ Robert. A. Dahl, A Preface to Economic Democracy, dalam kata pengantar yang ditulis oleh Dorojatun Kuntjorojakti, Yayasan Obor Indonesia, Jakarta, 1992, hlm. Xiii. Dikutip oleh Heru Nurtjahjo, ibid., 
berkampanye untuk memperoloeh dukungan atau suara; (6) terdapat berbagai sumber informasi; (7) ada pemilihan yang bebas dan jujur; (8) semua lembaga yang bertugas merumuskan kebijakan pemerintah, harus bergantung kepada keinginan rakyat. ${ }^{18}$

Ada beberapa hal yang pokok dari delapan unsur tesebut dalam kaitannya dengan pemberdayaan kedaulatan rakyat di Indonesia, antara lain mendapat kesempatan yang sama untuk dipilih atau menduduki berbagai jabatan pemerintahan negara, pemilihan yang bebas dan jujur, dan semua lembaga yang ada dalam merumuskan kebijaksanaan pemerintah harus bergantung kepada keinginan rakyat. Hal-hal tersebut selama bertahun-tahun khususnya pada era orde baru hanya sekadar wacana politik belaka, tetapi realisasinya masih jauh dari harapan. Oleh karena itu, dalam pembangunan negara demokrasi di masa depan sudah saatnya praktik-praktik demokrasi yang semu ditinggal dan diganti dengan demokrasi yang sesungguhnya, yaitu demokrasi yang menempatkan rakyat sebagai penentu utama dalam penyelenggaraan negara baik dalam bidang pemerintahan, politik, ekonomi, maupun sosial budaya. ${ }^{19}$

Demokrasi mempunyai arti penting bagi masyarakat yang menggunakannya, sebab dengan demokrasi hak masyarakat untuk menentukan sendiri jalannya organisasi negara dijamin. ${ }^{20}$ Demokrasi sebagai dasar hidup bernegara member pengertian bahwa pada tingkat terakhir rakyat memberikan ketentuan dalam masalah-masalah pokok yang mengenai kehidupannya, termasuk dalam menilai kebijaksanaan negara, oleh karena kebijaksanaan

18 Bagir Manan, Pelaksanaan Demokrasi Pancasila dalam Pembangunan Jangka Panjang II, Makalah dalam Lokakarya Pancasila, Unpad, Bandung, 1994, hlm. 2. Dikutip Juanda, Hukum Pemerintahan daerah, Pasang Surut Hubungan Kewenangan anaara DPRD dan Kepala Daerah, Alumni, Bandung, 2008, hlm. 17-18.

${ }^{19}$ Ibid., hlm. 18.

${ }^{20}$ Moh. Mahfud MD, Demokrasi dan Konstitusi di Indonesia, Rineka Cipta, Jakarta, 2003, hlm. 19. 
tersebut menentukan kehidupan rakyat. ${ }^{21}$ Jadi, negara demokrasi adalah negara yang diselenggarakan berdasarkan kehendak dan kemauan rakyat, atau jika ditinjau dari sudut organisasi, negara demokrasi berarti suatu pengorganisasian negara yang dilakukan oleh rakyat sendiri atau atas persetujuan rakyat, karena kedaulatan berada di tangan rakyat. ${ }^{22}$ Meskipun dari berbagai pengertian itu, bahwa rakyat diletakkan pada posisi sentral "rakyat berkuasa" (government or role by the people) tetapi dalam praktiknya oleh UNESCO disimpulkan bahwa ide demokrasi itu dianggap ambigu atau mempunyai arti ganda, sekurangkurangnya ada ambiguity atau ketentuan mengenai lembaga-lembaga tau caracara yang dipakai untuk melaksanakan ide, atau mengenai keadaan cultural serta historik yang mempengaruhi istilah, ide, dan praktek demokrasi. ${ }^{23}$

Pancasila sebagai dasar (falsafah) negara, pandangan hidup, ideologi nasional, dan pemersatu dalam peri kehidupan kebangsaan dan kenegaraan Indonesia. Pancasila adalah dasar statis yang mempersatukan sekaligus bintang penuntun (Leitstar) yang dinamis, yang mengarahkan bangsa dalam mencapai tujuannya. Pancasila merupakan sumber jati diri, kepribadian, moralitas, dan haluan keselamatan bangsa. ${ }^{24}$

Soekarno mengemukakan tentang urgensi Pancasila bagi bangsa Indonesia sebagai berikut:

"tetapi, kecuali Pancasila adalah satu Weltanschauung, satu dasar falsafah, Pancasila adalah satu alat mempersatu, yang saya yakin seyakin-yakinnya Bangsa Indonesia dari Sabang sampai ke Merauke hanyalah dapat bersatu padu di atas dasar Pancasila itu. Dan bukan saja alat mempersatu untuk diatasnya kita letakkan Negara Republik Indonesia, tetapi juga pada hakekatnya satu alat mempersatu dalam perjuangan kita melenyapkan segala penyakit yang telah kita lawan berpuluh-puluh tahun yaitu penyakit terutama sekali, imperialisme. Perjuangan suatu bangsa, perjuangan melawan imperialisme, perjuangan

${ }^{21}$ Deliar Noer, Pengantar ke Pemikiran Politik, CV Rajawali, Jakarta, 1983, hlm. 207.

${ }^{22}$ Amir Machmud, Demokrasi, Undang-undang dan Peran Rakyat, LP3ES, Jakarta, 1984.

${ }^{23}$ Miriam Budiardjo, ibid., hlm. 50.

${ }^{24}$ Yudi Latif, Negara Paripurna, Historisitas, Rasionalitas, dan Aktualitas Pancasila, PT Gramedia Pustaka Utama, Jakarta, 2012, hlm. 41. 
mencapai kemerdekaan, perjuangan sesuatu bangsa yang membawa corak sendiri-sendiri. Tidak ada dua bangsa yang cara berjuangnya sama. Tiap-tiap bangsa mempunyai cara berjuang sendiri, mempunyai karakteristik sendiri. Oleh karena pada hakekatnya bangsa sebagai individu mempunyai kepribadian sendiri. Kepribadian yang terwujud dalam pelbagai hal, dalam kebudayaannya, dalam perekonomiannya, dalam wataknya dan lain-lain sebagainya". ${ }^{25}$

Sebagai basis moralitas dan haluan kebangsaan-kenegaraan, Pancasila memiliki landasan ontologis, epistemologis, dan aksiologis yang kuat. Setiap sila memiliki justifikasi historisitas, rasionalitas, dan aktualitasnya yang jika dipahami, dihayati, dipercayai, dan diamalkan secara konsisten dapat menopang pencapaian-pencapaian agung peradaban bangsa. ${ }^{26}$

Menurut alam pemikiran Pancasila, nilai ketuhanan, nilai kemanusiaan dan nilai serta cita-cita kebangsaan itu dalam aktualisasinya harus menjunjung tinggi kedaulatan rakyat dalam semangat permusyawaratan yang dipimpin oleh hikmat kebijaksanaan. Dalam visi demokrasi permusyawaratan, demokrasi memperoleh kesejatiannya dalam penguatan daulat rakyat, ketika kebebasan politik erat menjadi satu dengan kesetaraan ekonomi yang menghidupkan semangat persaudaraan dalam kerangka "musyawarah-mufakat". Dalam prinsip musyawarah-mufakat, keputusan tidak di dikte oleh golongan mayoritas, atau kekuatan minoritas elite politik dan pengusaha, meainkan dipimpin oleh hikmat/kebijaksanaan yang memuliakan daya-daya rasionalitas deliberatif dan kearifan setiap warga tanpa pandang-bulu. Gagasan demokrasi permusyawaratan di Indonesia yang menekankan konsensus dan menyelaraskan demokrasi politik dan demokrasi ekonomi itu sangat visioner. Gagasan demokrasi seperti itu mendahului yang disebut dengan model "demokrasi deliberatif" yang memiliki kesejajaran dengan "sosial-demokrasi". ${ }^{27}$

${ }^{25}$ Soekarno, Pantja-Sila Sebagai Dasar Negara, Kementerian Penerangan RI, Jakarta, 1958, hlm. 3. Dikutip oleh Yudi Latif, ibid.,

${ }^{26}$ Ibid.,hlm. 42.

${ }^{27}$ Ibid., 
Demokrasi di Indonesia terus berkembang seiring dengan perkembangan zaman dan pengaruh politik yang begitu besar. Tetapi, terlepas dari itu semua, demokrasi dalam pemerintahan desa itu sudah berlangsung sejak Indonesia belum merdeka.

\section{B. Pemerintahan Desa di Indonesia}

Negara Indonesia adalah negara hukum. ${ }^{28}$ Negara hukum tumbuh pertama kali ada pada zaman liberal di Eropa Kontinental. Oleh karena itu, bentuk pemerintahannya yang liberal, maka negaranya disebut sebagai negara hukum liberal. Isi dari pengertian negara hukum ini mengalami perubahan dalam perkembangan yang mula-mula historis menjadi ideal. Timbulnya pengertian negara hukum liberal dipelopori oleh seorang ahli filsafat zaman itu, Immanuel Kant. Sejak saat itu, istilah negara hukum (rechsstaat) tidak berubah sampai sekarang dipakai, tetapi bukan negara hukum dalam arti liberal atau negara hukum dalam arti formal yang muncul pada masa berikutnya, persetujuan antara Pemerintah dan rakyat menimbulkan bentuk tertentu dalam peraturan perundang-undangan yang dipelopori oleh Friedrich Julius Stahl, melainkan negara hukum dalam arti material atau luas. Tipe negara hukum kemudian menjadi populer yang seterusnya dianggap sebagai suatu tipe negara yang ideal, sehingga hampir setiap konstitusi memasukkan istilah "negara hukum". ${ }^{29}$

Ajaran negara hukum atau negara berdasar atas hukum, Bagir Manan mengemukakan:

Ajaran negara berdasarkan atas hukum (de rechtsstaat dan the rule of law) yang mengandung esensi bahwa hukum adalah supreme dan kewajiban bagi setiap penyelenggara negara atau pemerintahan untuk tunduk pada hukum (subject to the law). Tidak ada kekuasaan di atas hukum (above to the law). Semuanya ada di bawah hukum (under the rule of law). Dengan kedudukan ini tidak boleh ada kekuasaan yang sewenang-wenang (arbitrary power) atau penyalahgunaan kekuasaan (misuse of power), baik pada kerajaan maupun republik. Secara maknawi, tunduk pada hukum, mengandung pengertian pembatasan kekuasaan seperti halnya ajaran pemisahan kekuasaan atau pembagian kekuasaan. Oleh

${ }^{28}$ Pasal 1 ayat (3) UUD 1945

${ }^{29}$ Padmo Wahjono, Ilmu Negara, Ind-Hill-Co, Jakarta, 1999, hlm. 112-113. 
karena itu, ajaran negara berdasarkan atas hukum memuat unsur pemisahan atau pembagian kekuasaan. Prinsip negara berdasarkan atas hukum dijalankan, seperti pada negara kerajaan (Inggris, Belanda, Jepang, Malaysia, dan lain-lain) maupun pada negara republik (Amerika Serikat, India, Singapura, Perancis, Jerman, dan lain-lain). ${ }^{30}$

Berkaitan dengan arti negara hukum atau negara berdasarkan hukum, Bagir Manan dan Kuntana Magnar membaginya ke dalam dua arti, yaitu dalam arti umum dan dalam arti khusus, yaitu:

Dalam arti umum, negara berdasarkan hukum adalah negara dimana ada saling percaya antara rakyat dan pemerintah. Rakyat percaya pemerintah tidak akan menyalahgunakan kkuasaannya, dan sebaliknya pemerintah percaya bahwa dalam menjalankan wewenangnya, pemerintah akan dipatuhi dan diakui oleh akyat. Sedangkan dalam arti khusus, negara berdasarkan hukum diartikan bahwa semua tindakan negara atau pemerintah harus didasarkan pada ketentuan hukum atau dapat dipertanggungjawabkan secara hukum. ${ }^{31}$

Negara Indonesia adalah negara kesatuan yang berbentuk republik. ${ }^{32}$

Menurut Moh. Kusnardi dan Hermaily Ibrahim:

Istilah negara kesatuan adalah susunan negaranya hanya terdiri atas satu negara saja dan tidak dikenal adanya negara di dalam negara seperti halnya pada suatu negara federal. ${ }^{33}$

Menuut Abu Daud Busroh, bahwa negara kesatuan adalah:

Negara yang tidak tersusun daripada beberapa negara, seperti halnya dalam negara federasi, melainkan negara itu sifatnya tunggal, artinya hanya ada satu negara, tidak ada negara di dalam negara. Jadi dengan demikian, didalam negara kesatuan itu juga hanya ada satu pemerintahan, yaitu pemerintahan pusat yang mempunyai kekuasaan atau wewenang tertinggi dalam segala lapangan

${ }^{30}$ Bagir Manan, Lembaga Kepresidenan, PSH UII \& Gama Media, Yogyakarta, 1999, hlm. 11-12.

${ }^{31}$ Bagir Manan dan Kuntana Magnar, Mewujudkan Kedaulatan Rakyat Melalui Pemilihan Umum, Gaya Media Pratama, Jakarta, 1996, hlm. 67.

32 Pasal 1 ayat (1) UUD 1945

${ }^{33}$ Moh. Kusnardi dan Hermaily Ibrahim, Pengantar Hukum Tata Negara Indonesia, Pusat Studi Hukum Tata Negara FH UI dan CV Sinar Bakti, Jakarta, 1983, hlm. 249. 
pemerintahan. Pemerintahan pusat inilah yang pada tingkat terakhir dan tertinggi dapat memutuskan segala sesuatu dalam negara tersebut. ${ }^{34}$

Sedangkan menurut Ernst Utrecht, memberikan batasan tentang negara kesatuan adalah:

Suatu negara yang tidak terdiri atas beberapa daerah yang berstatus negara bagian (deelstaat) dengan undang-undang dasar sendiri, biasanya juga dengan kepala negara sendiri dan menteri-menteri sendiri-sendiri, serta merdeka dan berdaulat. ${ }^{35}$

Konstitusi UUD 1945 juga menyatakan bahwa, kedaulatan berada di tangan rakyat dan dilaksanakan menurut Undang-Undang Dasar. ${ }^{36}$ Secara umum, kata "kedaulatan" mengandung arti kemerekaan, kuasa tertingi, dan sekaligus kekuatan. Berkenaan dalam arti kekuatan dari kedaulatan, maka kedaulatan itu bersifat absolut ke dalam, tetapi terbatas ke luar wilayah negara. ${ }^{37}$ Pengertian kedaulatan telah beberapa kali berubah. Mula-mula kedaulatan berarti kekuasaan absolut, kekuasaan tertinggi, dan tidak terbagi-bagi. Kemudian kedaulatan mempunyai arti yang relatif, dalam arti kekuasaan tertinggi mengenai beberapa hal dan dengan demikian terbagi-bagi. ${ }^{38}$

Teori kedaulatan rakyat dapat menjadi pemerintahan berkedaulatan rakyat terjalin erat dan melekat dengan teori kedaulatan hukum. Ada tiga asumsi pemerintahan berkedaulatan rakyat yang berdasar atas hukum, yaitu: (1) Pemerintahan berkedaulatan rakyat adalah Pemerintahan yang memiliki kekuasaan terbatas atau dibatasi; (2) Pemerintahan berkedaulatan rakyat adalah pemerintahan yang mengakui kemajemukan masyarakat (pluralistik); (3) Pemerintahan berkedaulatan rakyat menolak adanya setiap upaya untuk

\footnotetext{
${ }^{34}$ Abu Daud Busroh, Ilmu Negara, Bumi Aksara, Jakarta, 1990, hlm. 64-65.

${ }^{35}$ Ernst Utrecht, Pengantar Dalam Hukum Indonesia, Sinar Harapan, Jakarta, 1983, hlm. 342.

${ }^{36}$ Pasal 1 ayat (2) UUD 1945

${ }^{37}$ Astim Riyanto, Negara Kesatuan, Konsep, Asas, dan Aktualisasinya, YAPEMDO, Bandung, hlm. 39

${ }^{38}$ Miriam Budiardjo, Dasar-Dasar Ilmu Poliik, PT. Gramedia, Jakarta, 1981, hlm. 16
} 
memutlakan suatu pandangan atau pikiran mengenai masyarakat dan moral.sikap ini antara lain akan mewujudkan toleransi dalam perikehidupan bernegara dan bermasyarakat. ${ }^{39}$

Teori kedaulatan rakyat secara kontroversial sangat berpengaruh sekali dalam sejarah kekuasaan negara. Ide dasarnya sangat sederhana, bahwa rakyatlah yang harus menjadi sumber kekuasaan tertinggi dalam suatu negara. Rakyat berkuasa secara independen atas dirinya sendiri. Suatu zaman yang hanya dilingkupi oleh kekuasaan para penguasa yang menyebut dirinya sebagai raja atau kaisar, pikiran untuk menempatkan rakyat sebagai penguasa tertinggi atau pemegang kedaulatan adalah suatu yang mustahil. Namun demikian, gagasan kedaulatan rakyat ini kemudian terus berkembang dalam diskusi teori kenegaraan dan juga praktik trial and eror baik di Prancis, Amerika, hingga akhirnya diikuti oleh hampir seluruh negara di dunia. ${ }^{40}$ Desa adalah suatu perwujudan geografis yang ditimbulkan oleh unsur-unsur fisiografis sosial ekonomis, politis dan kultural yang terdapat di situ dalam hubungan dan pengaruh timbal balik dengan daerah-daerah lain. ${ }^{41}$

\footnotetext{
${ }^{39}$ Bagir Manan, Hubungan antara Pusat dan Daerah Menurut UUD 1945. Pustaka Sinar Harapan, Jakarta, hlm. 17

${ }^{40}$ Menurut bahasa Indonesia istilah "kedaulatan rakyat" seringkalidigunakan dan diidentikkan dengan "demokrasi". Walaupun dari segi etimologi tidak menimbulkan masalah serius, senyatanya dua istilah ini dapat memiliki interpretasinya sendiri-sendiri. Kedaulatan rakayat atau demokrasi dalam teks Indonesia memiliki nuansanya sendiri secara konseptual. (Lihat tulisan Moh. Hatta, "Ke Arah Indonesia Merdeka" dimuat dalam buku "Masalah Kenegaraan" yang diedit oleh Miriam Budioardjo. Dikutip oleh Heru Nurtjahjo, op.cit., hlm. 33.

${ }^{41}$ R. Bintarto, Sosial Buku Penuntun Geografi, UP Spring, Yogyakarta, 1968, hlm. 95. Dikutip oleh Hanif Nurcholis, Pertumbuhan \& Penyelenggaraan Pemerintahan Desa, Penerbit Erlangga, Jakarta, 2011, hlm. 4.
} 
Menurut Hanif Nurcholis, bahwa desa dapat juga diartikan sebagai:

"Suatu wilayah yang didiami oleh sejumlah penduduk yang saling mengenal atas dasar hubungan kekerabatan dan/atau kepentingan politik, sosial, ekonomi, dan keamanan yang dalam pertumbuhannya menjadi kesatuan masyarakat hukum berdasarkan adat sehingga tercipta ikatan lahir batin antara masingmasing warganya, umumnya warganya hidup dari pertanian, mempunyai hak mengatur rumah tangga sendiri, dan secara administratif berada di bawah pemerintahan kabupaten/kota", ${ }^{4}$

Perkembangan Sistem Pemerintahan Desa di Indonesia dengan diberlakukannya Undang-Undang Nomor 6 Tahun 2014 tentang Desa, bahwa Pemerintahan Desa adalah penyelenggaraan urusan pemerintahan dan kepentingan masyarakat setempat dalam sistem pemerintahan Negara Kesatuan Republik Indonesia. ${ }^{43}$ Menurut perkembangannya, seiring dengan keterlibatan Desa dalam Administrasi Negara, Desa dijadikan sebagai bagian terkecil dalam struktur pemerintahan negara, pembantu Kepala Desa yang utama adalah Sekretaris Desa (Sekdes) atau juga disebut carik, seriang, penyarikan, juru tulis atau panitera. Di desa-desa tugas pemerintahan desanya bertambah banyak, pembantu Kepala Desa bukan hanya seorang Sekretaris Desa, tetapi juga perangkat Desa yang menangani bidang pekerjaan tertentu seperti: bidang keamanan (polisi desa, kepetengan, tamping, jogoboyo, kepala jaga polisi, mayulu ho'lopo); bidang agama dan atau adat (penghulu, mukim, imam, modin, kaum pemangku dan lain-lain), bidang kesejahteraan rakyat (jogo tirto, ulu-ulu, kemakmuran, juru air). ${ }^{44}$

Berhubungan dengan desa-desa yang wilayahnya luas, karena tempat pemukiman penduduk tersebar secara tidak merata, wilayah desa terbagi dalam kesatuan-kesatuan wilayah yang lebih kecil atau disebut Dusun, Kampung,

\footnotetext{
42 Ibid.,

${ }^{43}$ Pasal 1 butir (2) Undang-undang Nomor 6 Tahun 2014 tentang Desa

${ }^{44}$ Mashuri Maschab, Politik Pemerintahan Desa di Indonesia, POLGOV, Yogyakarta, 2013, hlm. 6.
} 
Pedukuhan, dan lainnya, yang masing-masing dipimpin oleh kepalanya sendirisendiri, yang juga bertindak sebagai pembantu Kepala Desa. Jadi, dengan struktur semacam itu, maka organisasi pemerintahan desa sama seperti organisasi pemerintahan nasional, seperti Presiden dibantu oleh para menteri yang bertugas di bidang tertentu, dan kepala-kepala wilayah/daerah yang memimpin pemerintahan dilingkungannya sendiri. ${ }^{45}$ Melaksanakan kedaulatan bagi rakyat adalah dengan cara menentukan atau turut menentukan sesuatu kebijakan kenegaraan tertentu yang dapat dilakukan sewaktu-waktu menurut tata cara tertentu. ${ }^{46}$ Demokrasi Pancasila merupakan demokrasi yang konstitusional berdasarkan mekanisme kedaulatan rakyat di setiap penyelenggaraan negara dan penyelenggaraan pemerintahan menurut konstitusi yaitu Undang-Undang Dasar 1945.

\section{Implementasi Demokrasi Pancasila dalam Sitem Pemilihan Kepala Desa}

\section{(Studi Kasus Pemilihan Kepala Desa Secara Serentak di Kabupaten Banyumas)}

Kabupaten Banyumas terletak di wilayah Provinsi Jawa Tengah dengan ibukotanya adalah Purwokerto. Kabupaten Banyumas berbatasan dengan Kabupaten Brebes disebelah utara, Kabupaten Purbalingga, Kabupaten Banjarnegara dan Kabupaten Kebumen disebelah timur, serta Kabupaten Cilacap disebelah selatan dan barat. Pemilihan Kepala Desa di Kabupten Banyumas diselenggarakan secara serentak oleh 257 desa pada tanggal 23 Juli

\footnotetext{
45 Ibid.,

46 Jimly Asshiddiqie, Pokok-Pokok Hukum Tata Negara Indonesia, PT Bhuana Ilmu Populer, Jakarta, 2007, hlm. 738-739.
} 
2019 yang ditetapkan berdasarkan Keputusan Bupati Banyumas Nomor 140/633 Tahun 2018 tanggal 14 Desember 2018. ${ }^{47}$

Pelaksanaan pemilihan kepala desa secara serentak di Kabupaten Banyumas diikuti oleh 785 orang calon kepala desa (kades) di 257 desa yang tersebar di Kecamatan Tambak, Kecamatan Sumpiuh, Kecamatan Kemranjen, Kecamatan Kebasen, Kecamatan Banyumas, Kecamatan Kalibagor, Kecamatan Wangon, Kecamatan Sumbang, Kecamatan Cilongok, Kecamatan Kedung, dan Kecamatan Ajibarang, lima persen diantaranya masih memiliki hubungan keluarga. Ada yang memiliki hubungan suami istri, bapak dan anak, ataupun kerabat dekat seperti paman dan keponakan. Para calon kepala desa yang memiliki hubungan kekerabatan itu, salah satunya adalah petahana dan merupakan calon tunggal. Oleh karena itu, supaya pemilihan kepala desa dapat dilaksanakan, maka istri, suami, bapak, anak, paman dan keponakan maju sebagai calon kepala desa untuk menjadi lawannya. Misalnya di Desa Ajibarang Kulon Kecamatan Ajibarang, calon kepala desanya antara suami dan istrinya, yang dimenangkan oleh suaminya. Adapun untuk jumlah pemilih dalam Daftar Pemilih Tetap (DPT) adalah 6.312 orang, yang hadir dan menggunakan hak pilihnya 4.777 orang, sementara itu kartu suara tidak sah 173 lembar. Perolehan suara tersebut Mochammad Solikhin 3.952 suara dan istrinya Umroh Sadiyah mendapatkan 652 suara. Pelaksanaan penghitungan suara tersebut sesuai dengan ketentuan peraturan perundang-undangan yang berlaku. ${ }^{48}$

Pemilihan kepala desa secara serentak yang dilaksanakan di Kabupaten Banyumas tersebut merupakan contoh implementasi dari demokrasi Pancasila dalam pemerintahan desa di Indonesia. Apabila dihubungkan dengan peraturan perundang-undangan khususnya Undang-Undang Nomor 6 Tahun 2014 tentang Desa, maka sistem pemilihan Kepala Desa diatur dalam Pasal 31 sampai dengan Pasal 39 UU Nomor 6 Tahun 2014 tentang Desa. Pasal 31 UU Nomor 6 Tahun 2014 tentang Desa menyebutkan bahwa: (1) Pemilihan Kepala Desa

${ }^{47}$ http://www.kicaunews.com. 24-Juli-2019.

${ }^{48}$ Ibid., 
dilaksanakan secara serentak di seluruh wilayah Kabupaten/Kota; (2) Pemerintahan Daerah Kabupaten/Kota menetapkan kebijakan pelaksanaan pemilihan Kepala Desa secara serentak sebagaimana dimaksud pada ayat (1) dengan Peraturan Daerah Kabupaten/Kota; (3) Ketentuan lebih lanjut mengenai tata cara pemilihan Kepala Desa serentak sebagaimana dimaksud pada ayat (1) dan ayat (2) diatur dengan atau berdasarkan Peraturan Pemerintah. Kemudian Pasal 34 UU Nomor 6 Tahun 2014 tentang Desa menyebutkan bahwa: (1) Kepala Desa dipilih langsung oleh penduduk Desa; (2) Pemilihan Kepala Desa bersifat langsung, umum, bebas, rahasia, jujur, dan adil; (3) Pemilihan Kepala Desa dilaksanakan melalui tahap pencalonan, pemungutan suara, dan penetapan. Pemilihan Kepala Desa merupakan suatu implementasi demokrasi Pancasila di Indonesia yang harus terus diselenggarakan dengan langsung, umum, bebas, rahasia, jujur dan adil. Karena nilai-nilai Pancasila yang terkandung dalam sila keempat diantaranya bahwa pemerintahan desa itu berasal dari rakyat, oleh rakyat dan untuk rakyat.

\section{PENUTUP}

\section{A. Simpulan}

Implementasi pemilihan Kepala Desa secara serentak di Kabupaten Banyumas dapat diselenggarakan dengan baik, apabila didukung oleh warga masyarakatnya, walaupun ada calon Kepala Desa yang berasal dari satu keluarga, tetapi hal itu tidak mengurangi dari hakikat demokrasi Pancasila. Keterlibatan masyarakat dalam menyalurkan hak pilihnya itu sangat berarti sekali dalam menentukan pemerintahan desa kedepannya. Peraturan perundang-undangan, khususnya yang berhubungan dengan pemilihan kepala desa itu sangat diperlukan sekali dalam regulasi penyelenggaraan pelaksanaan pemilihan Kepala Desa. Sebab, dengan adanya peraturan perundang-undangan tersebut, maka apabila yang dapat menimbulkan kecurangan-kecurangan dan permasalahan-permasalahan dalam pemilihan Kepala Desa itu dapat dicegah. Sehingga dapat terwujudnya suatu pemerintahan desa yang baik. 


\section{B. Saran}

Sebaiknya pemilihan Kepala Desa itu diselenggarakan secara serentak di seluruh Indonesia, supaya pemerintah pusat dapat memantau pelaksanaan pemilihan Kepala Desa dalam sistem pemerintahan desa secara menyeluruh, dengan tidak menghilangkan kekhasan atau kearifan lokal yang tetap hidup di masyarakat tersebut. 


\section{DAFTAR PUSTAKA}

\section{A. BUKU}

Abu Daud Busroh, Ilmu Negara, Bumi Aksara, Jakarta, 2014.

Amir Machmud, Demokrasi, Undang-undang dan Peran Rakyat, LP3ES, Jakarta, 1984.

Astim Riyanto, Negara Kesatuan, Konsep, Asas, dan Aktualisasinya, YAPEMDO, Bandung, 2010.

Bagir Manan, Hubungan Antara Pusat dan Daerah, Sinar Harapan, Jakarta, 1994. , Lembaga Kepresidenan, PSH-UII \& Gama Media, Yogyakarta,

1999.

Bagir Manan \& Kuntana Magnar, Mewujudkan Kedaulatan Rakyat Melalui Pemilihan Umum, Gaya Media Pratama, Jakarta, 1990.

B.N. Marbun, Otonomi Daerah 1945-2010 Proses \& Realita, Sinar Harapan, Jakarta, 2010.

Deliar Noer, Pengantar ke Pemikiran Politik, CV Rajawali, Jakarta, 1983.

Ernst Utrecht, Pengantar Dalam Hukum Indonesia, Sinar Harapan, Jakarta, 1983.

Hanif Nurcholis, Pertumbuhan \& Penyelenggaraan Pemerintahan Desa, Penerbit Erlangga, Jakarta, 2011.

I Gde Pantja Astawa, Problematika Hukum Otonomi Daerah di Indonesia, Alumni, Bandung, 2009.

Jimly Asshiddiqie, Pokok-Pokok Hukum Tata Negara, PT Bhuana Ilmu Populer, Jakarta, 2007. Jakarta, 2009.

Juanda, Hukum Pemerintahan Daerah, Pasang Surut Hubungan Kewenangan antara DPRD dan Kepala Daerah, Alumni, Bandung, 2008.

Kaelan, Pendidikan Pancasila, PARADIGMA, Yogyakarta, 2010.

Mashuri Maschab, Politik Pemerintahan Desa di Indonesia, POLGOV, Yogyakarta, 2013.

Miriam Budiardjo, Dasar-Dasar Ilmu Politik, PT Gramedia, Jakarta, 1981.

Moh. Kusnardi dan Hermaily Ibrahim, Pengantar Hukum Tata Negara Indonesia, Pusat Studi Hukum Tata Negara FH UI dan CV Sinar Bakti, Jakarta, 1983. 
Moh. Mahfud MD, Demokrasi dan Konstitusi di Indonesia, Rineka Cipta, Jakarta, 2011.

Nata Irawan, Tata Kelola Pemerintahan Desa, Yayasan Pustaka Obor Indonesia, Jakarta, 2017.

Padmo Wahjono, Ilmu Negara, Indo-Hill-Co, Jakarta, 1999.

R. Bintarto, Sosial Buku Penuntun Geografi, UP Spring, Yogyakarta, 1968.

Soekarno, Pantja-Sila Sebagai Dasar Negara, Kementeriaan Penerangan RI, Jakarta, 1958.

Ubaedillah \& Abdul Rozak, Pendidikan Kewarga(Negara)an (Civic Education), Pancasila, Demokrasi, HAM, dan Masyarakat Madani, Kencana Prenada Group, Jakarta, 2010.

Yudi Latif, Negara Paripurna Historisitas, Rasionalitas, dan Aktualitas Pancasila, PT. Gramedia Pustaka Utama, 2014.

\section{B. Peraturan Perundang-Undangan}

Undang-Undang Dasar 1945

Undang-Undang Nomor 9 Tahun 2015 tentang Perubahan Kedua Atas UndangUndang Nomor 23 Tahun 2014 tentang Pemerintahan Daerah

Undang-Undang Nomor 6 Tahun 2014 tentang Desa

\section{Website/Internet}

Sotrisno, Pemkab Banyumas Umumkan Hasil Pemenang Pilkades Serentak 2019, diakses http://www.kicaunews.com 24 Juli 2019 diakses tanggal 15 Agustus 2019. 